\title{
The Structure of the Flower of Fagaceae, and its Bearing on the Affinities of the Group.
}

\author{
BY
}

E. M. BERRIDGE, B.Sc., F.L.S.

With nine Figures in the Text.

OF the families usually classed together under the term Amentiferae, the Fagaceae has received less thorough investigation at the hands of botanists than almost any other division of this great group. The chalazogamic forms have naturally attracted attention, and those with very simple flowers have been carefully examined, in the hope that they would reveal primitive characters. Yet the possibility remains that the Amentiferae, or at all events certain families among them, are not primitive, but reduced forms of some other angiospermic alliance ; if this be the case the Fagaceae, including Fagus, Castanea, Castanopsis, and Quercus, would be just the division most likely to indicate such an affinity, possessing as they do more complete flowers than the rest of the group.

The opposite view, that the Amentiferae are directly derived from certain gymnospermous families, was held by Eichler (8), and was also brought forward prominently by Treub (23) after the discovery of chalazogamy. Engler (9), accepting Treub's view, and considering this character peculiar to Casuarina, placed this genus in a separate group, the Verticillatae, a connecting link between the Angiosperms and Gymnosperms, where it still remains isolated in his system, although more recent work has shown that Casuarina differs in no essential manner from other Amentiferae $(4,10)$, and that chalazogamy prevails among the Coryleae, Betuleae, and Juglandaceae ${ }^{1}(3,17,18)$.

Nawaschin, in his elaborate study of the Birch and Alder, suggests the derivation of the Betuleae from the Coniferae, and of the Casuarineae from the Gnetales, and arrives at the conclusion that the placentae and ovules arise from the organic axis of the flower independently of the carpels, a view supported by Nicoloff (19) on anatomical grounds. Wettstein, in

${ }^{1}$ For a concise discussion of the systematic position of Casuarina see Moss, C. E. : Modern Systems of Classification. New Phyt., vol. xi, p. 209, I9I 2.

[Annals of Botany, Vol. XXVIII. No. CXI. July, 19s4.] 
his Systematic Botany, works out this theory in fuller detail, and grapples with the difficulty of deriving the bisexual flowers from the simpler unisexual forms ; his solution, however, is based on the hypothesis that the flower is a reduced inflorescence, and if applied to such a case as Castanea would involve a most intricate series of reductions and modifications to account for the varying and elaborate character of the epigynous, multipartite flower.

A modification of this view has been recently brought forward by Lignier (15), who, after giving a minute description of the anatomy of the flower of Welwitschia, concludes that the Gnetales are very primitive Angiosperms, and that they form the starting-point of a phylogenetic series which contains the amentiferous alliances, this series being parallel to that to which the main body of Angiosperms belongs.

On the other hand, for morphological reasons, Prantl (20) looks upon the Fagaceae and Betulaceae as derived by reduction from plants bearing bisexual flowers possessing a perianth, multilocular ovary, and suspended ovules, but he considers that the two families have been developed inde. pendently, the Fagaceae being the more primitive of the two.

Goebel (11) and Arber and Parkin (1) also regard the Fagales and Juglandales as reduced forms, the latter pointing out that the superior gamophyllous perianth, syncarpous ovary, and complicated inflorescence are not features likely to be characteristic of a primitive family.

Van Tieghem $(24,25)$ was the first to show that the floral anatomy of Fuglans and of the Coryleae was similar to that of the higher Angiosperms ; this conclusion was opposed by Nicoloff (10), who emphasized certain details in the structure of the flower of Juglans, on which he based his view that the ovule in this genus was axial and not appendicular; finally Benson and Welsford (5), in a more recent study of the same and allied genera, confirmed Van Tieghem's view, and showed that the placental bundles arise from the carpellary traces. The observations of Nicoloff, however, are of interest as indicating an essential likeness in the structure of the flower in Fuglans and in the Fagaceae, which will be more fully dealt with in another part of this paper.

Quite recently the view that the Cupuliferae are a primitive family has received support from the study of the structure of the foliar rays of the wood by several American observers. No high degree of primitiveness, however, is here claimed for the Amentiferae, but only a degree relative to other Angiosperms, which would be quite consistent with the derivation of the group from bisexual flowering plants also possessing somewhat primitive characteristics, for a similar early type of wood structure is said to occur also in the Ericaceae and Platanaceae $(22,2)$, and in certain shrubby Rosaceae (7).

None of the writers who regard the Amentiferae as derived from 
angiospermous forms possessing bisexual flowers suggest affinity with any modern group of Archichlamydeae, but seem, rather, to incline to Coulter's (6) conclusion that, ' whether they represent a single genetic stock or several, they appear to be isolated from the higher alliances.'

Hallier has attempted to demonstrate an affinity between the Cupuliferae and one or other of the higher groups of Dicotyledons. In his earlier scheme for the classification of the Angiosperms (12), he derived the Cupuliferae from the Hamamelidaceae, and through this order from the Laurineae, thus connecting them indirectly with rosalian forms allied to the Combretaceae; in later papers, however, he discarded this view in favour of the theory that they were descended from the Anacardiaceae and Burseraceae, chiefly on account of the strong anatomical likeness of Fuliania to these orders on the one hand, and to Fuglans on the other (13).

But this view, based on the characteristics of some of the most reduced members of long reduction series, does not seem to take sufficiently into account the more complex members of the group, such as the Fagaceae, and the facts brought forward in the following pages seem to a certain extent to confirm the earlier theory, that the ancestors of the Cupuliferae were nearly allied to the Rosaceae. ${ }^{1}$

\section{Morphological Characters of CAStanopsis CHRysophylla.}

Castanopsis chrysophylla, the Golden-leaved Chestnut, a Californian shrub sometimes grown in English gardens, was selected for special study, as being one of the less well-known members of the Fagaceae. The fact, moreover, that it possesses flowers which, though functionally female, are structurally bisexual, with an androecium of twelve stamens constantly present, seemed to promise that its investigation would throw light on the organization of the more reduced forms in the group.

The genus is very closely allied to Castanea, the chief points in which it differs from the latter being the trilocular form of the ovary, and the irregularity of the cupule; the latter is sometimes absent, and sometimes encloses, according to Prantl (20), only one flower. This writer regards the genus Castanea as a branch of the large tropical family Castanopsis, which has become adapted to northern temperate climates.

The flowering branches of Castanopsis chrysophylla bear numerous catkins; the lower ones, growing in the axils of the leaves, are entirely staminate, and though closely resembling those of Castanea vulgaris, are shorter and smaller. Only two or three small catkins in the axils of bracts

1 In a more recent paper, L'Origine et le Système phylétique des Angiospermes (Archives Néerlandaises des Sci. Nat., sér. 3 B., t. i, I9I2, p. I 46), Hallier, while still adhering to his later view, admits the possibility of the derivation of the Amentaceae from the Hamamelidaceae or Rosaceae, particularly in view of certain likenesses in the anatomical structure of the wood. 
near the apex of the shoot bear fertile pistillate flowers, and of these the upper ones are abortive.

The longer staminate catkins are not infrequently branched at the base, and the tufts of flowers on them also appear to be telescoped branches. These tufts usually contain from four to six dichasia, the secondary flowers of which are well developed; sometimes tertiary flowers are also present. The tufts on the female catkins may contain as many as ten well-developed flowers, at the base of each of which appear two small secondary buds, all densely packed together. As will be shown later on, in a separate section of this paper, these secondary axes give rise to the 'valves' of the cupule ; hence, in the later stages, each ripening nut appears to be furnished with a separate cupule.

Each tuft of flowers is surrounded by numerous hairy bracts, which presumably are the subtending bracts of the dichasia, as they correspond in number to the latter, but are frequently somewhat displaced; in addition, two primary lateral bracteoles enclose each dichasium, and are clearly distinguishable even after the appearance of the cupule. Four or five of the ovaries of a single tuft of flowers develop into nuts, but of these only one, or occasionally two, contain embryos; in the others only the dead remains of ovules are to be found; hence it appears that parthenocarpy is prevalent here as in other members of the Amentiferae.

\section{Flowers.}

The staminate flowers possess in all cases a rudimentary ovary, and are evidently reduced forms of the perfect flowers from which the nuts develop.

Both male and female flowers possess a gamophyllous perianth of six leaves, the three alternate lobes being larger and overlapping the others. The perianth is thickly covered with simple unbranched hairs, those on the outer surface and edges of the lobes being thick-walled, and growing in tufts of two to four together. Among these simple hairs are scattered multicellular glandular hairs somewhat peltate in form.

All the flowers are completely epigynous, and possess two whorls of six stamens inserted at the junction of the perianth and ovary. The six stamens of the outer whorl, which are opposite to the lobes of the perianth, are slightly adnate to the latter, and develop somewhat earlier than the six stamens which alternate with them. The anthers are introrse and versatile, and the filaments are very long, as in Castanea, and strongly incurved in the bud. The pollen of the flowers which are functionally pistillate seems perfectly normal, and like that of the staminate flowers; the grain shows three longitudinal furrows with a pore in the middle of each furrow, and two nuclei can be clearly distinguished within it. The female flowers are strongly protogynous, the stigmas protruding when the stamens are still curled up 
in the bud ; they are, therefore, pollinated by the pollen from the staminate flowers on the lower catkins of the same or other plants. In Castanea also, this must necessarily be the case, for the stamens of the female flowers seldom contain any fully developed pollen-grains. Cross fertilization is probably effected, to some extent, by bees, which sometimes visit Sweet Chestnut trees in great numbers. Eichler (8) only mentions the presence of 'six staminodia opposite the perianth lobes' in the female flowers of Castanea; but more than six are sometimes to be found, and from their position it is evident that twelve is the original number, arranged as in C. chrysophylla.

These genera may be added, therefore, to the numerous cases fully described by Kerner (14), where a diclinous plant shows marked protogyny. It seems obvious that extreme protogyny might in certain cases tend to a separation of the sexes, for the early development of the stigmas would naturally lead to the pollination of the pistils on the younger branches by pollen from flowers on the older ones of the inflorescence. This tendency would render the pistils of the older and earlier flowers and the stamens in the younger later flowers comparatively useless, and prepare the way for their elimination.

That such a process might be much modified by other circumstances, such as the relative positions of the flowers, is evident, when such complex cases of dichogamy as those among the Umbelliferae are taken into consideration, but in the Fagaceae a series of stages in the process appears to be represented, for while in Castanopsis we have apparently functional stamens in the female flowers, in Castanea we find these stamens containing little or no good pollen; in the Oak they are reduced usually to mere papillae, while in the Beech as a rule they are entirely absent.

The ovary in Castanopsis, as in the other Fagaceae, is completely fused with the receptacular cup, and though usually trilocular, four or even more loculi frequently are present, particularly in the flowers growing at the apex of each tuft. The three main loculi occur opposite the larger perianth lobes, the extra one appearing opposite the smaller lobes. The placentation is axile, and the ovules, like those of Castanea, are paired, suspended, bitegumentary, and epitrope.

The ovary of the staminate flower at the time of opening is not merely rudimentary as in Castanea, but shows an interesting stage of arrested development. The six placental margins can be clearly seen projecting into the cavity of the ovary, but not meeting in the middle. The lower half of each margin is fused with the neighbouring one, but above it becomes free and runs up into the style. Between the style and the stamens the ovary wall grows up into a disc-like ring of tissue, so that the style appears to be inserted nearly half-way down towards the base. 
No upgrowth of the apex of the flower axis to meet the ingrowing septa was observed in any young stages of development in Castanopsis, but in some hand sections of young ovaries of Quercus cerris gathered on January 16 such an upgrowth was found to be present.

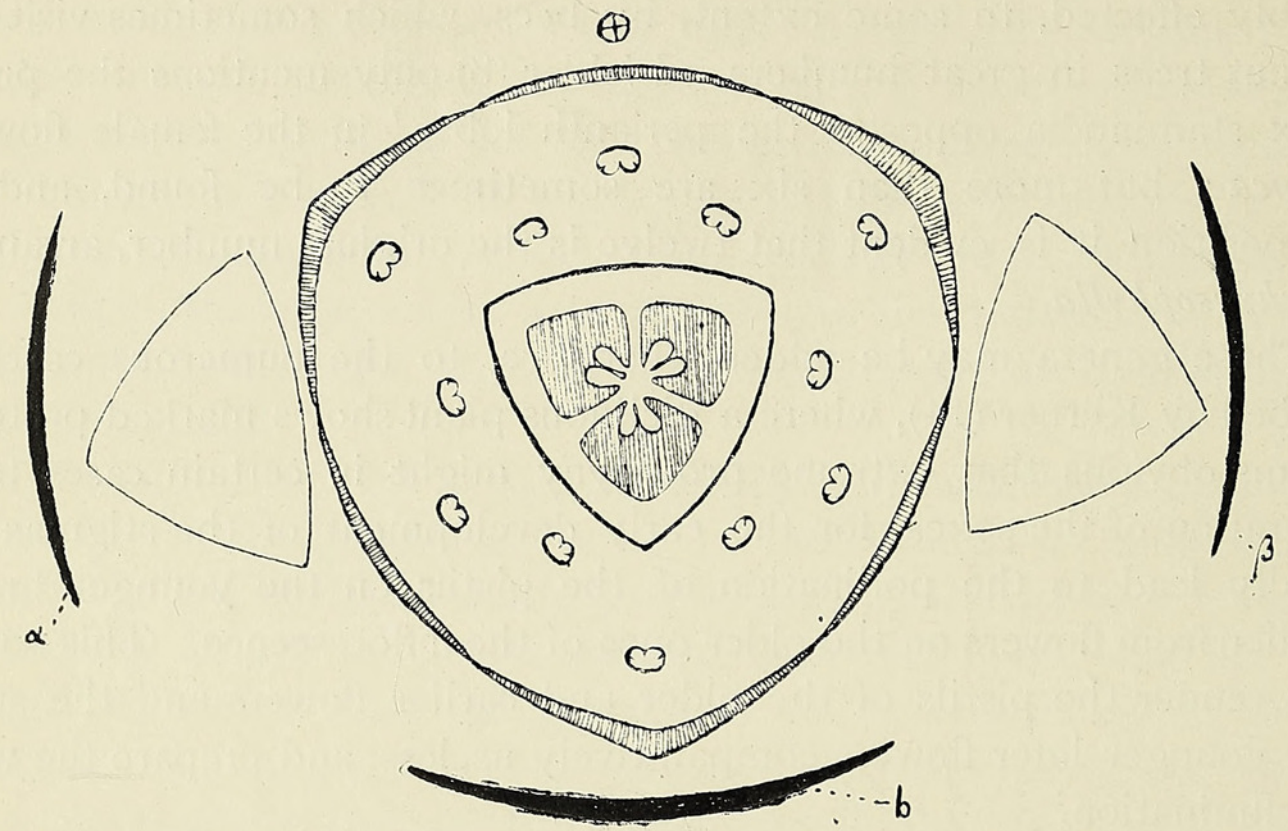

FIG. I. Floral diagram of Castanopsis chrysophylla. b., subtending bract of dicha $a, \beta$, bracteoles of primary flower.

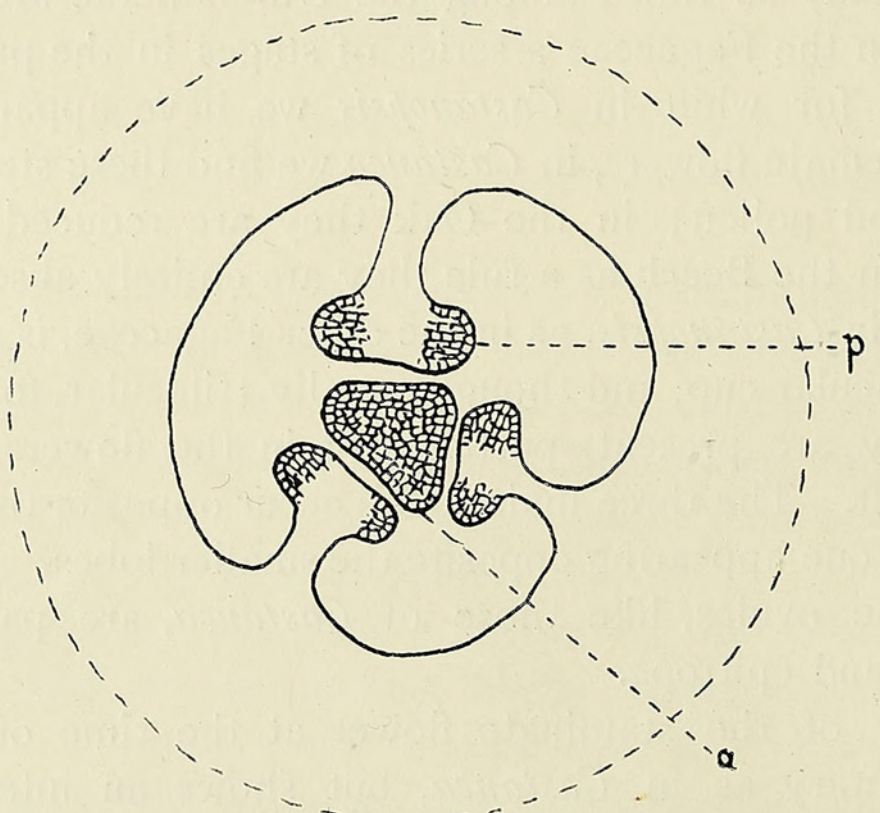

FIG. 2. Cross-section of young ovary of Quercus cerris. a., apex of flower axis ; $p$., placenta. $\times 9^{\circ}$.

Fig. 2 is a sketch of one of these sections, showing that this prolongation of the axis is quite independent of the septa, and that the latter alone bear the placentae, on which young ovules are already present. Later the placental tissue seems to fuse with and entirely surround this 
Fagaceae, and its Bearing on the Affinities of the Group. 5I5 axial prolongation, thus forming the greater part of the central column of the ovary, including the outer layers in which the ovular bundles run.

The fruit of C. chrysophylla, like that of some of the Oaks, takes two years to develop. At the time of pollination, about the middle of July, ovules are present, but the archesporial cells are hardly distinguishable from the rest of the nucellar tissue, and the integuments are only beginning to appear. Little development takes place during the winter months, and fertilization does not occur in England till the latter half of the month of May.

\section{Cupule.}

There can be little doubt that in Castanopsis chrysophylla each valve of the cupule represents, not a bracteole covered with emergences, as

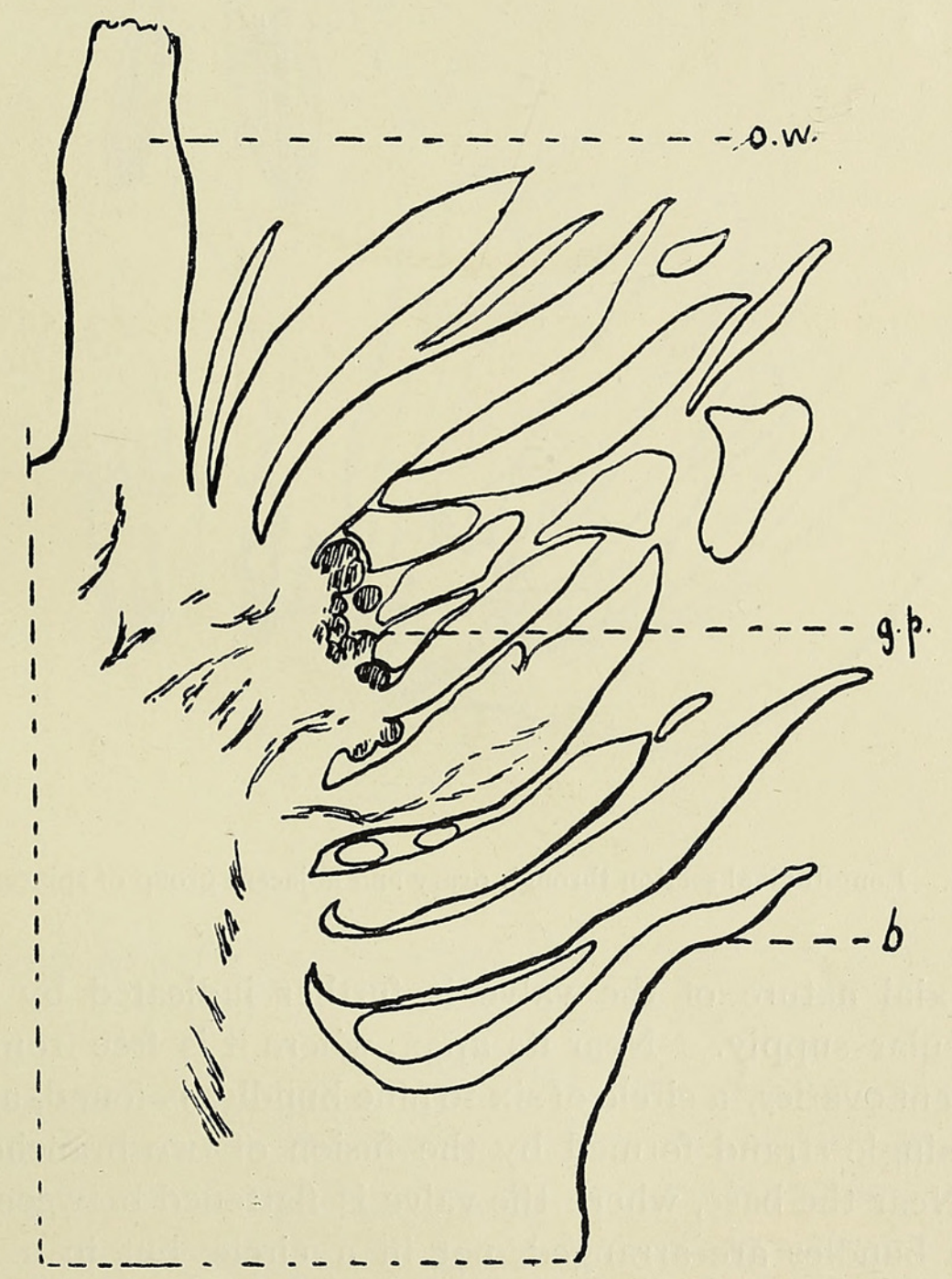

FIG. 3. Commencement of cupule valve, showing its growing-point $(g \cdot p$.$) and its position$ corresponding with that of the secondary flower of the dichasium. o.w., ovary wall of primary flower ; $b$., bract of primary flower. $\times 45$.

Eichler suggests in his account of the cupule of other members of the Fagaceae, but one of the secondary axes of the dichasium, beset with 
spinous bracts. At the time of flowering, that is, about the middle of July, the lower flowers in the tufts borne by the female catkins are flanked by sessile buds with well-defined growing points (Fig. 3). These doubtless represent the secondary flowers of the dichasia. Round the upper terminal flowers of the tufts these outgrowths are so compressed that their nature cannot easily be recognized, but they too appear to have a growing point round which the young spines cluster, and they also therefore are probably axial in nature. A month later these buds have developed into groups of spines as large and conspicuous as the ovaries themselves, and in the axils of many of the spines tiny buds appear (Fig. 4).

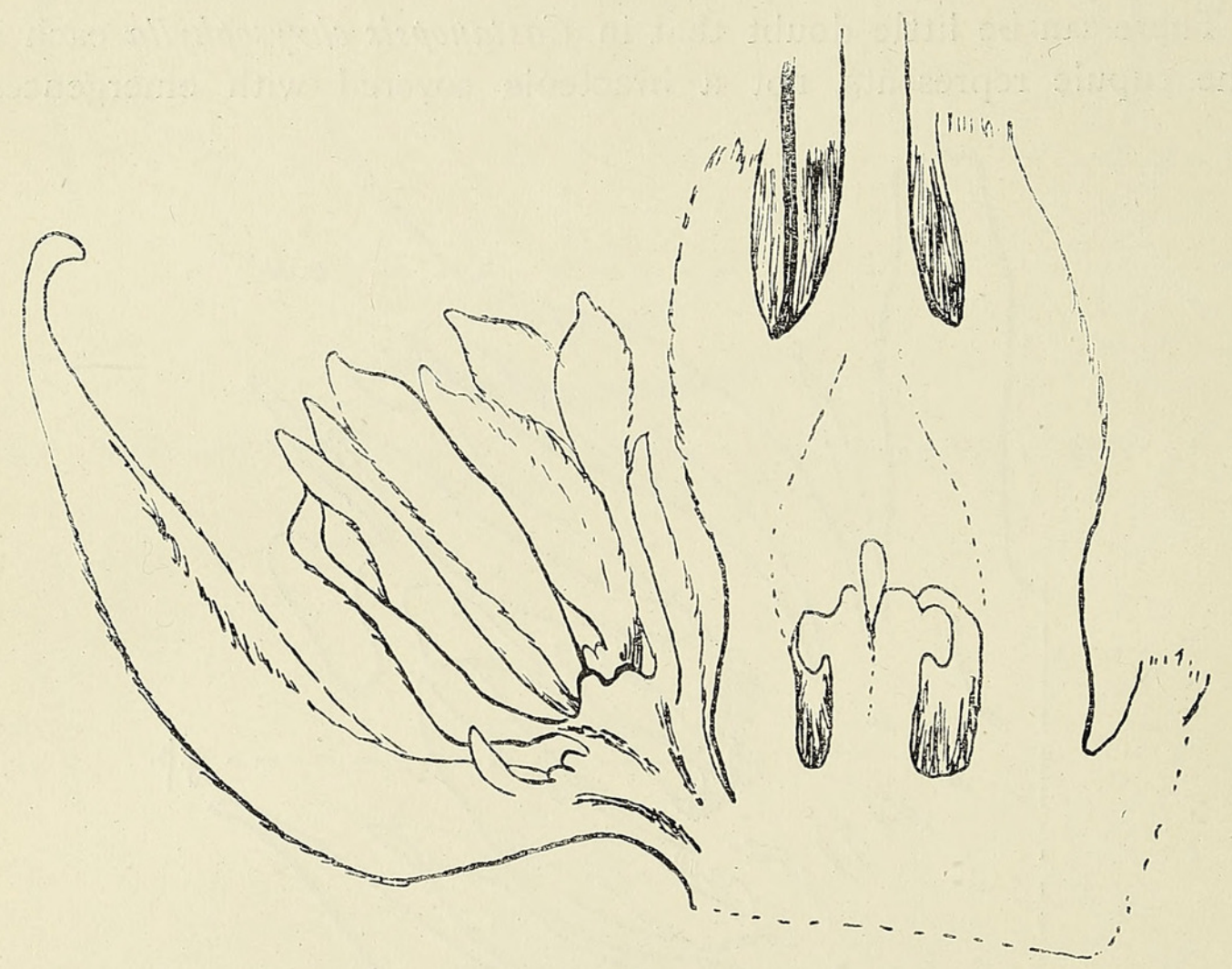

FIG. 4. Longitudinal section through ovary and adjacent group of spines. $\quad \times 30$.

The axial nature of the valve is further indicated by the character of the vascular supply. Near its apex, where it is free from the pressure of the adjacent ovaries, a circle of six to nine bundles is found, and each spine receives a single strand formed by the fusion of two branches from these bundles. Near the base, where the valve is flattened between the growing ovaries, the bundles are arranged, not in a circle, but in a straight line, being evidently displaced by the pressure to which the whole organ is subjected.

Little further development occurs till near the time of fertilization, about the middle of the following May, when the 'cupule valves' begin to grow quickly till they entirely cover the nuts with a mass of sharp branch- 
Fagaceae, and its Bearing on the Affinities of the Group. 5I 7

ing spines. Three such 'valves' usually separate each nut from its neighbours, but this trimerous arrangement is only an effect of pressure, for, as we have seen, the valves represent axes which form part of dichasial inflorescences.

Prantl (20) was able to distinguish in several species of Pasania two bracteoles below the cupule, and hence concluded that it must in these cases be an outgrowth of the axis of the primary flower, and that the many scales on it were metamorphosed leaves; he also extended this view to the

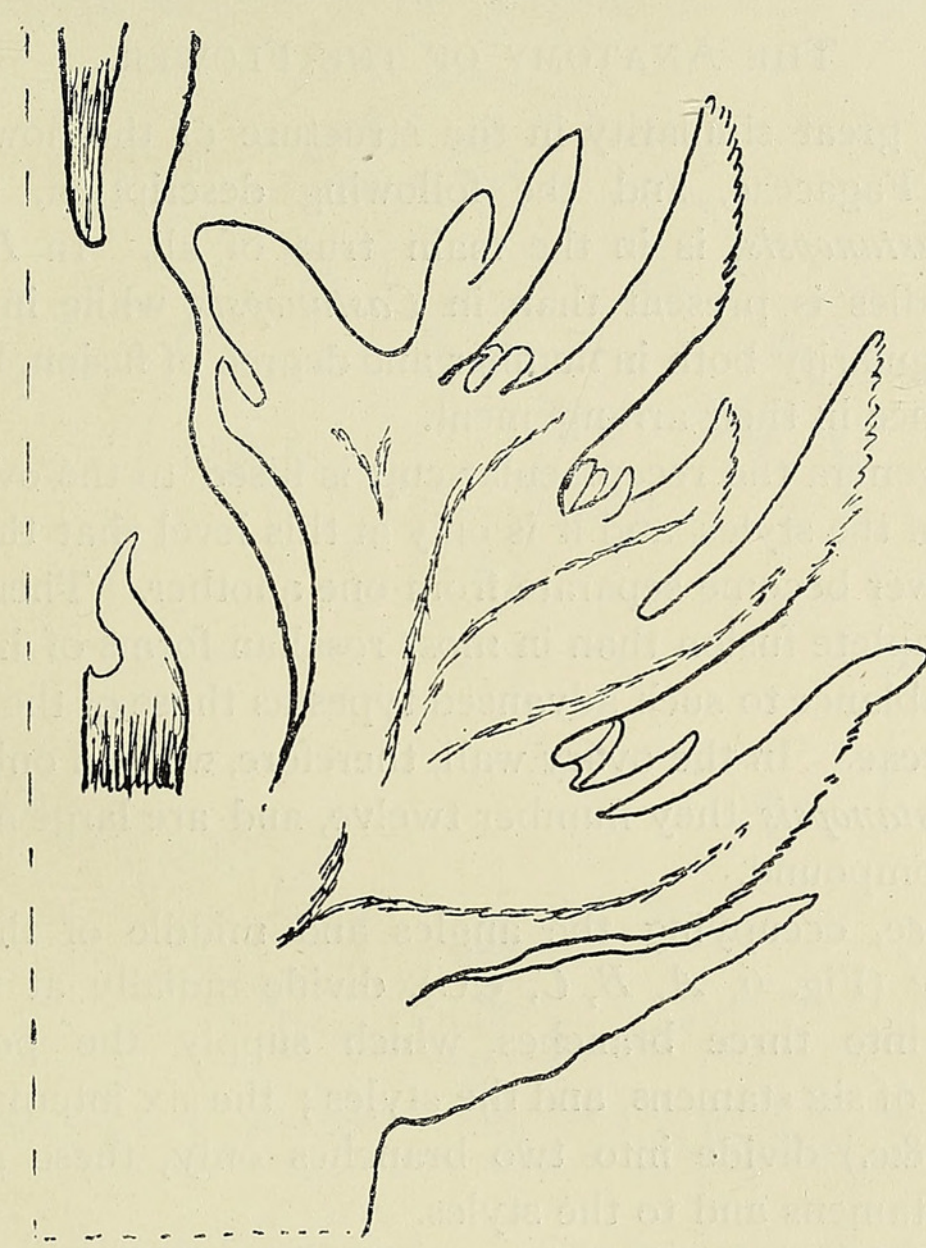

FIG. 5. Longitudinal section through ovary and adjacent cupule valve, just before the time of fertilization. $\times 44$.

cupules of Quercus where the primary bracteoles are not clearly distinguishable. He states that the secondary flowers of the dichasia are present in Pasania, and therefore regards the cupule as an intercalary growth; he points out that the reduced leaves appear upon it in acropetal succession, but seem to be retarded till after the development of the floral leaves at the apex of the shoot.

If, however, we extend what seems a perfectly obvious interpretation of the cupule in the case of Castanopsis chrysophylla to Quercus, and regard its cupule also as a modification of the fused secondary axes of the dichasium, 
it is evident that the scales, i. e. the leaves, on these might naturally develop later than the floral leaves of the primary axis.

All the evidence, in fact, which is brought forward by Prantl in support of his conclusion that the cupule is an intercalary growth of the axisfor instance, the leaf-like nature of the cupular scales in Fagus Sieboldii, or the appearance of bracts below and prior to the outgrowth of the valves in Castanea -is equally applicable in support of the view that the valves are modified secondary or tertiary axes, and not, as Eichler maintained, merely bracts covered with emergences.

\section{The Anatomy of the Flower.}

There is a great similarity in the structure of the flower of the four genera of the Fagaceae, and the following description, which applies primarily to Castanopsis, is in the main true of all. In Fagus a larger number of bundles is present than in Castanopsis, while in Quercus they show much irregularity both in number and degree of fusion, but there is no essential difference in their arrangement.

In all the genera the receptacular cup is fused to the ovary wall right up to the base of the styles, and it is only at this level that the traces of the parts of the flower become separate from one another. There is, therefore, much more complete fusion than in most rosalian forms of inferior ovaries, and more resemblance to such advanced types as those of the Philadelpheae and Curcurbitaceae. In the ovary wall, therefore, we find only one series of bundles; in Castanopsis they number twelve, and are large and fan-shaped and evidently compound.

Six of these, occupying the angles and middle of the sides of the triangular ovary (Fig. $6, A, B, C, \& \mathrm{c}$.), divide radially at the margin of the receptacle into three branches, which supply the perianth leaves, the outer whorl of six stamens, and the styles; the six intermediate bundles (Fig. 6, $a, b, c, \& c$.) divide into two branches only, these passing to the inner whorl of stamens and to the styles.

In view of the fact that these intermediate bundles $(a, b, c, \& \mathrm{c}$.) originate in exactly the same manner as the whorl of $\operatorname{six}(A, B, C, \& c$.) from which the perianth bundles spring, it is not unreasonable to suppose that they primitively supplied a whorl of petals, and that the inner whorl of stamens is an antipetalous series, although we have no direct evidence of the previous existence of a corolla in these genera.

In Castanea the number of bundles in the ovary wall is often increased by branches from the original twelve, while in Fagus a group of strands occurs in each angle of the nut and spreads out into the wing; each seems to be equivalent to three or four wall-bundles with the component traces less closely associated together, and this brings the total number of these main bundles up to 18 or 20 . 
In addition to the bundles in the wall, the central column of the ovary contains a circle of small vascular strands (Fig. 6, o.p.b.) which resolve themselves into six amphiphloic bundles passing into the funicles of the six seeds. Also in Castanopsis, but in that genus only, three tiny vascular strands (Fig. 6, i.p.b.) occupy the middle of this circle; these only become lignified and therefore easily distinguishable in the course of the second year of development of the ovary; they can be traced above the point where the ovular bundles pass out of the column, and occupy the intermediate positions opposite the septa. Each probably represents two fused marginal bundles of the carpels, or they may possibly have

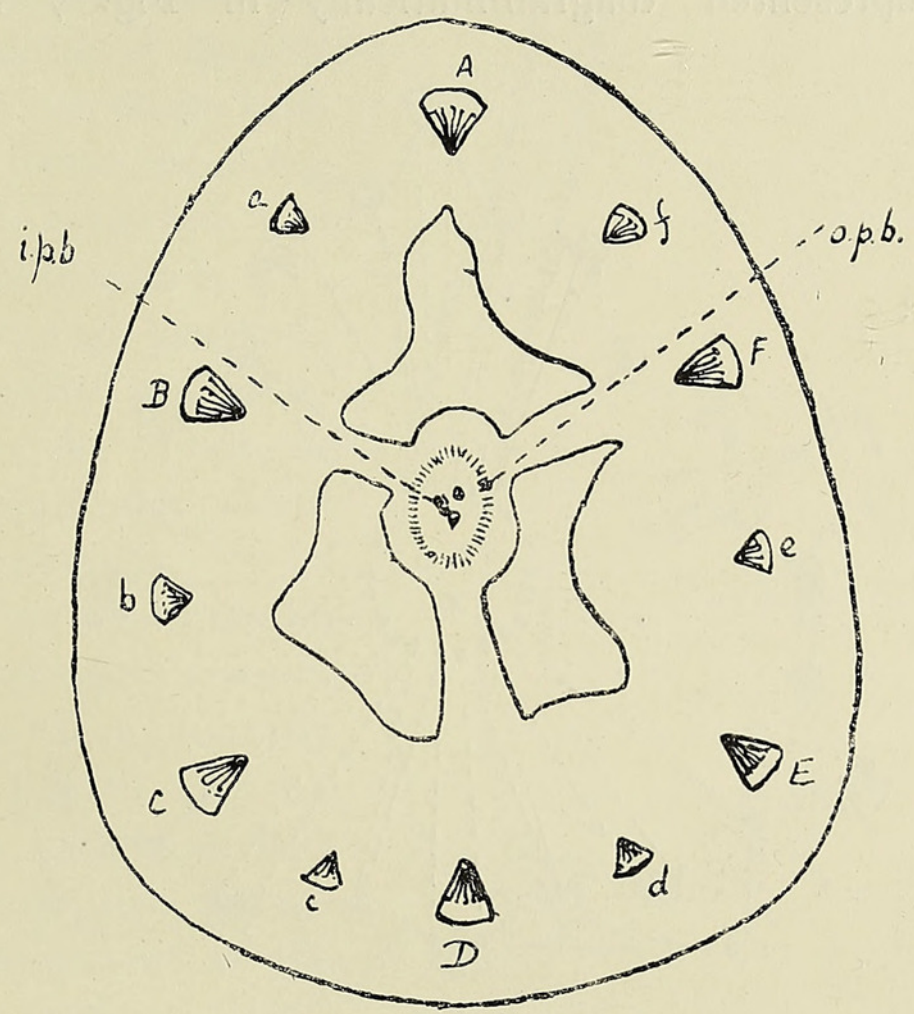

FIG. 6. Transverse section of lower part of ovary. A, B, C, \&c., $a, b, c$, \&c., main bundles of the ovary wall; o.p.b., outer placental bundles; i.p.b., inner placental bundles.

originally supplied additional ovules at a higher level than the two now constantly present in each loculus. They may possibly be axial, but their orientation does not support this view, and in Castanopsis no upgrowth of the apex of the flower axis between the carpels was observed, though in Quercus cerris such an elongation of the axis occurs.

In the pedicel of the flower, below the level at which the loculi begin to appear, another set of twelve bundles (Fig. 7, c.b.) is present, alternating with the main bundles (Fig. 7, m.b.) of the ovary wall. These supply the carpels, and originate as a rule by the fusion of two branches from the neighbouring main bundles. While still in the base of the ovary these carpellary bundles break up into a number of vascular strands. The lowest, running inwards, fuse with similar branches to form 
the three tiny bundles in the middle of the placental column. At a slightly higher level two more branches pass outwards and become associated with the neighbouring main bundles. These dorsal bundles (Fig. 7, d.b.) probably fuse in pairs during the course of the main bundles up the ovary wall, and each fused pair reappears at the base of the styles as a single strand representing the dorsal bundle of the carpel.

In addition to the above, numerous anastomosing strands spring from the carpellary bundles themselves, and from their dorsal branches, and run inwards to form the circle of bundles in the placental column, which at a higher level breaks up into the ovular traces. These anastomosing strands are represented diagrammatically in Fig. 7 by the dotted

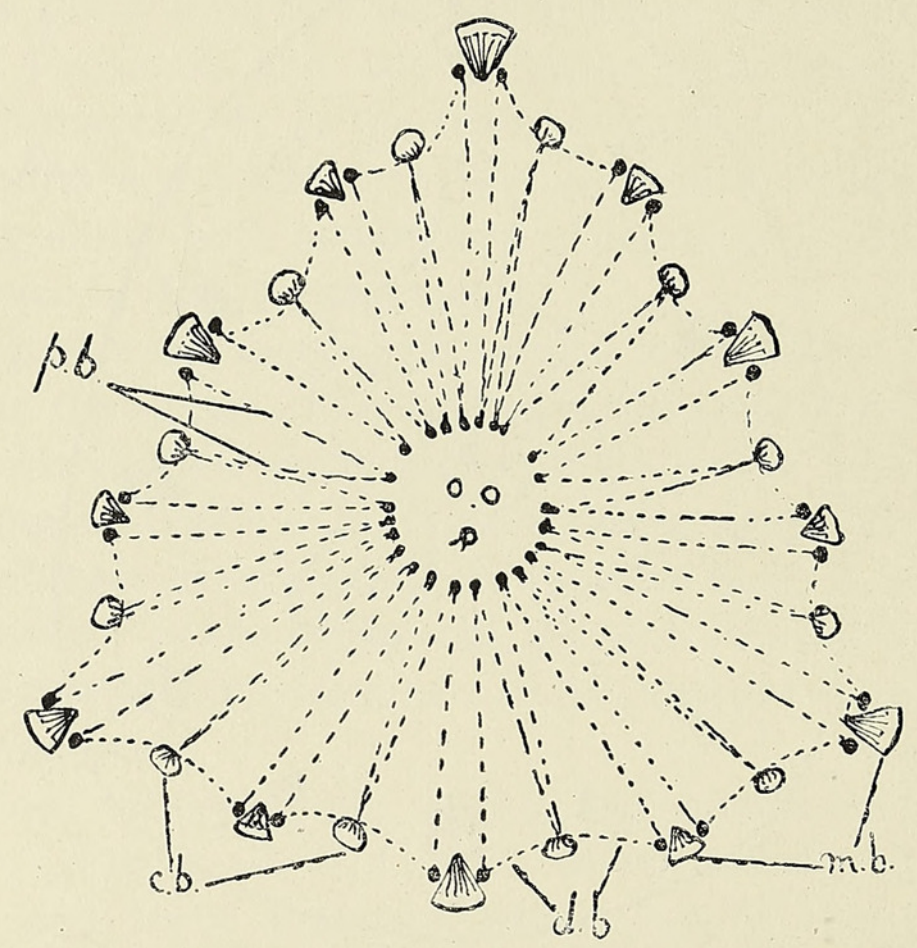

FIG. 7. Diagram representing arrangement of bundles in the base of the ovary of the flower of Castanopsis. m.b., main bundles of wall; c.b., carpellary bundles; $d . b$., branches running outwards to the main bundles; $p . b$., vascular strands running to the placenta.

lines p.\%. The dorsal branches almost invariably give off one of these placental strands just at the point where they join the main bundles of the wall, so that the latter, i. e. the perianth and stamen traces, appear to contribute to these ovular bundles, but in longitudinal sections it is quite clear that there is no direct union between the two sets of traces.

Fig. 8 shows the relations between two carpellary bundles (c.b.), with their numerous branches, and the neighbouring main bundles supplying perianth leaves and stamens. The common origin of these two sets of bundles, as well as the fusion of the dorsal stylar branches with the main bundles, are facts wholly unfavourable to Wettstein's view that this is one of the most primitive forms of bisexual flowers, and that it has arisen 
Fagaceae, and its Bearing on the Affinities of the Group. 52 I

through the association of originally independent male and female flowers within a common perianth.

In Castanea the structure of the flower is the same as in Castanopsis, and, apart from the greater number of main bundles in the ovary wall, it is the same in Fagus.

In Quercus the presence of groups of stone cells in the outer layers of the receptacular wall makes it almost impossible to cut thin serial sections of the ovary at the later stages when the bundles are fully lignified, but such sections as were obtained showed the presence of carpellary bundles below the loculi, breaking up into dorsal branches and placental strands just as in Castanopsis. The dorsal branches, however, frequently run independently up to the styles, so that the ovary wall often shows twenty or more bundles.

So far, in the examination of the flower, a trimerous structure is apparent throughout; it is only in the pedicel that we come across any indication that this trimery is adaptive, the result of the development of the flowers within a confined space. In Fagus the whole vascular supply of the flower springs from fifteen bundles arranged in three groups of five; in Castanopsis the same three groups of five main bundles may be traced, and
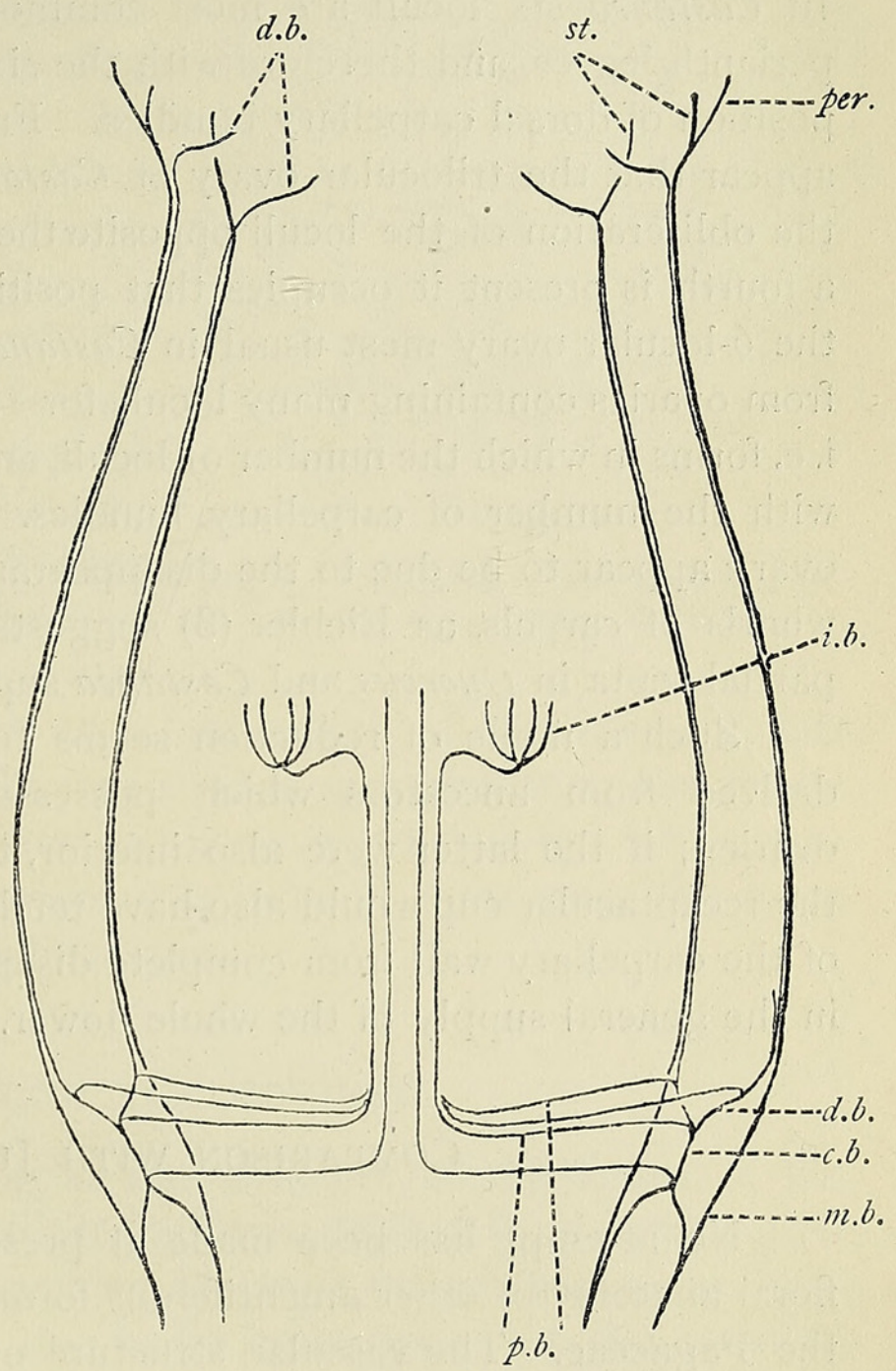

FIG. 8. Diagram of course of bundles in flower of Castanopsis chrysophylla. m.b., main bundles; per., branch to perianth; st., branch to stamen; d.b., branch to style; c.b., carpellary bundle; $p . b$. , placental branches; $i . b$., branches in the outer integument of ovule. frequently a fourth group is present, corresponding to a fourth loculus in the ovary, which, if fully developed, would bring the number of main bundles up to twenty. These fifteen to twenty bundles combine in various ways to give the twelve which traverse the ovary wall.

In Castanea, on the other hand, the middle flower of the dichasium, which is compressed on both sides, sometimes shows only two groups of five main bundles, the third group being altogether missing.

It seems not improbable, therefore, that the organs of the flower were 
originally arranged in multiples of five, and the possibility of a relationship with families prevailingly pentamerous must be taken into account.

It would appear to be a point of some significance that the vascular structure of the inferior ovary is practically identical in Castanea and Castanopsis. That structure corresponds rather with the multilocular condition in the former than with the trilocular form of the ovary in the latter. In Castanea six loculi are most commonly present, situated opposite the perianth leaves, and therefore with the six largest main bundles taking the position of dorsal carpellary bundles. From such an arrangement it would appear that the trilocular ovary of Castanopsis and Qucrcus is derived by the obliteration of the loculi opposite the smaller perianth leaves, for when a fourth is present it occupies that position. It is very probable also that the 6-locular ovary most usual in Castanea is derived in the same manner from ovaries containing many loculi, for I 2 -locular forms are not infrequent, i. e. forms in which the number of loculi, and therefore of carpels, corresponds with the number of carpellary bundles. The variations, therefore, in the ovary appear to be due to the disappearance of septa only, not of complete whorls of carpels, as Eichler (8) suggests, and the frequent occurrence of partial septa in Quercus and Castanea support this view.

Such a mode of reduction seems to indicate that the Fagaceae are derived from ancestors which possessed syncarpous and multilocular ovaries; if the latter were also inferior, the union of the outer walls with the receptacular cup would also have tended to preserve the vascular supply of the carpellary wall from complete disappearance, since it becomes merged in the general supply of the whole flower.

\section{COMPARISON WITH JUGLANS REGIA.}

No attempt has been made at present by the writer to work out the floral anatomy of other amentiferous forms with a view to a comparison with the Fagaceae. The vascular structure of the flower of Fuglans regia has, however, been very fully described by Van Tieghem (24) and Nicoloff (19), and also by Benson and Welsford (5), and has been the basis of much discussion concerning the affinities of the group; a comparison, therefore, can be readily made, and, moreover, seems to furnish an explanation of one of the features which led Nicoloff to insist so strongly on the axial nature of its ovule.

His Fig. I5, which represents a transverse section of the pedicel in Fuglans, and which is here reproduced (Fig. 9), differs from a section taken through the same region in Quercus Robur mainly in the fact that, while in the Oak the outer circle of bundles supplies the cupule only, and the inner supplies both perianth and carpels, here the cupule and perianth bundles are associated together in the outer circle, while the inner circle consists of 
bundles which supply only the ovule and styles. In Fuglans, four alone of these latter, two anterior and two posterior, behave as do the carpellary traces in the Fagaceae, giving off dorsal branches which fuse in pairs and run up to the stigmas, as well as placental strands which pass first horizontally and then vertically through the septa to the ovule. All the others, according to Nicoloff, contribute placental bundles only. This latter series of vascular strands, converging to the central column and then passing upwards to the ovule, was regarded by this author as belonging to the floral axis, but it seems probable that we have here a network of carpellary strands comparable to that present in the same position in the less reduced Amentiferae such as Quercus. Neither Van Tieghem nor Benson and Welsford

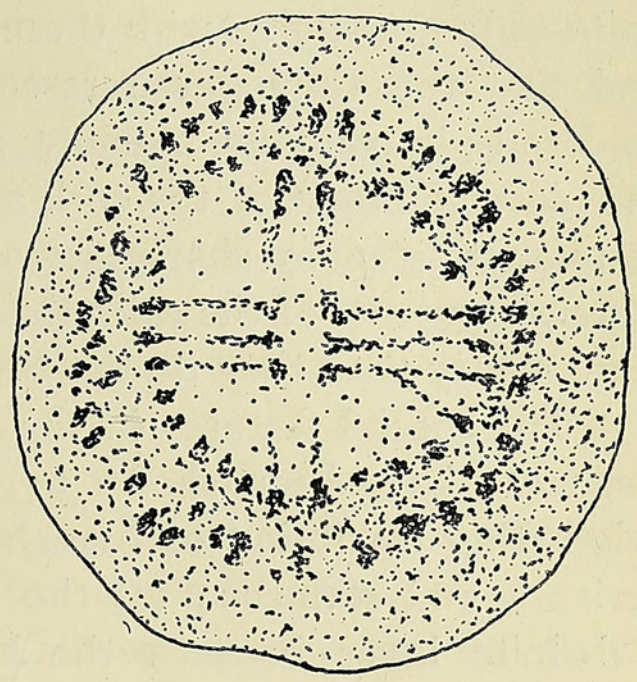

FIG. 9. Transverse section of pedicel in Fuglans regia. After Nicoloff. mention this vascular network, which probably only shows lignification at a late period of development, but include in their description only the four strands springing from the dorsal bundles of the carpels. It is interesting, however, to find the whole network still persisting, and thus linking this reduced form with the more complex multilocular ovary of the Fagaceae.

\section{Affinity with the Rosales.}

There appears to be nothing in the structure of the flower of the Fagaceae to preclude the view that the family is derived from some rather primitive angiospermic stock possessing bisexual flowers with syncarpous multilocular ovaries; there seem also to be indications that the ancestral flowers may also have been dichlamydeous, pentamerous, and epigynous.

These features, as well as the large number of characteristics common to the Fagaceae and Rosaceae which are summarized below, seem to point to ancestors allied to some of the epigynous types among the Rosales.

Besides the morphological characters already mentioned, we find prevailing in both genera the woody habit, alternate stipulate leaves, cymose or frequently dichasial inflorescences, and stamens, when present, arranged in at least two whorls, introrse, and strongly incurved in the bud. Where the ovary is syncarpous the placentation is axile, the ovules paired, bitegumentary, and epitrope, and the seeds exalbuminous.

The numerous resemblances in the anatomical structure of the vegetative organs can readily be traced in the 'Concluding Remarks' of 
Solereder's 'Systematic Anatomy of the Dicotyledons'. Hallier (13) has laid great stress upon these features in his comparison of the Cupuliferae with the Anacardiaceae and Burseraceae, but it may be observed that the Cupuliferae are classed together with the Rosaceae in Solereder's summary quite as frequently as with these members of the Terebinthales. Here we find that the Cupuliferae resemble the Rosaceae in the nature of the epidermis, hypoderma, stomata, and hairs, both ordinary and glandular, in the place of origin of the cork and in the structure of the pericycle; while in respect of many characters of the wood, the secretory system, and the mineral contents of the cells, the Cupuliferae seem to approach the Rosaceae more nearly than they do the Burseraceae and Anacardiaceae.

The special features in the anatomical structure of the flower of the Fagaceae have been shown to be (I) the presence of carpellary bundles originating by fusion of branches from the main bundles supplying the perianth and stamens; (2) the concentration of the placental strands in a definite layer beneath the loculi of the ovary, with a corresponding absence of vascular tissue in the septa; (3) the double nature of the dorsal bundles of the carpels. The carpellary bundles in the Pomeae bear a similar relationship to the perianth and stamen traces, and the placental bundles to which they give rise run inwards horizontally to the middle of the flower; while in Fuchsia and Oenothera, forms usually regarded as derived from the Pomeae, there is apparently a still closer resemblance in the distribution of the bundles, for Van Tieghem mentions a network of small strands running near the base of the loculi to the ovules, and notes the marked absence of vascular tissue in the septa. The dorsal bundle of the carpel is described by Van Tieghem as arising in the Pomeae by direct radial doubling of the sepal traces, but in Pyrus Aria, P. communis, P. Aucuparia, and Exochorda grandiflora, this does not appear to be the case; the dorsal bundle has been found to be of double origin, formed by fusion of two branches from the carpellary bundles, which alternate with the perianth traces. Hence in the details of vascular structure, as well as in general form, the flowers of the Rosaceae and Fagaceae show distinct resemblances.

Little stress can be laid on the occurrence of multicellular archesporia and chalazogamy in both alliances, for these characters appear in such isolated genera throughout the Dicotyledons that it is doubtful whether they are of any phylogenetic value. Aporogamy in particular appears to be due to an adjustment to some change of condition within certain ovaries which have undergone reduction. It seems quite evident, however, that these two characters can no longer be regarded as linking the Cupuliferae closely with the Gymnosperms.

Finally, two of the most marked features which separate the Fagaceae from the higher alliances-the trimerous nature of the flower and the form of the inflorescence-have been shown to be probably the result of a strong 
tendency in the family to aggregation of the flowers and economy in the parts, and the appearance of a cupule in these forms seems to be due to the same tendencies, since it is simply a modification of certain branches of the inflorescence for purposes of protection.

The numerous resemblances here enumerated between the Rosaceae and allied orders on the one hand, and the Fagaceae and other Cupuliferae on the other, can hardly be fortuitous, but seem to point to some real relationship between the groups. Complex forms like the Fagaceae can hardly have been derived from rosalian forms through the Hamamelidaceae, but this order would probably be included in the same cycle of affinity.

\section{SUMMARY.}

The inflorescence, flowers, and cupule of Castanopsis chrysophylla are described and the anatomical structure of the flower fully worked out.

The latter is compared with that of Castanea vulgaris, Fagus sylvatica, Quercus Robur, and Fuglans regia.

The flower is shown to differ in no essential from other epigynous types of angiospermic flowers, and a fairly detailed comparison is drawn between the Rosaceae and the Cupuliferae, since it seems probable that the epigynous Rosaceae or their near descendants are the forms with closest affinity to the ancestors of the Fagaceae.

\section{BIBLIOGRAPHY.}

1. Arber, E. Newell, and Parkin, J. : The Origin of the Angiosperms. Journ. Linn. Soc., Bot., vol. xxxviii, 1907, p. 29.

2. Bailey, J. W.: The Evolutionary History of the Foliar Ray in the Wood of the Dicotyledons, and its Phylogenetic Significance. Ann. of Bot., vol. xxvi, I91 2, p. 647.

3. Benson, M. J. : A Contribution to the Embryology of the Amentiferae, Pt. I. Trans. Linn. Soc., ser. 2, Bot., vol. iii, I 894, p. 409.

4. Benson, M. J., Sanday, E., and Berridge, E. M. : A Contribution to the Embryology of the Amentiferae, Pt. II, Carpinus. Trans. Linn. Soc., ser. 2, Bot., vol. vii, I906, p. 37.

5. Benson, M. J., and Welsford, E. J.: The Morphology of the Ovule and Female Flower of Fuglans regia, and of a few Allied Genera. Ann. of Bot., vol. xxiii, I909, p. 623.

6. Coulter, J. M., and Chamberlain, C. J.: Morphology of the Angiosperms, I903.

7. Eames, A. J.: On the Origin of the Herbaceous Type in the Angiosperms. Ann. of Bot., vol. xxv, I9II.

8. Eichler, A. W.: Blüthendiagramme, I878, pp. 20-30.

9. Engler, A. : Die natürlichen Pflanzenfamilien. Nachtrag, Pts. II-IV, Leipzig, I897.

10. FrYe, T. C.: The Embryo sac of Casuarina stricta. Bot. Gaz., vol. xxxvi, Aug., I908, p. 101 .

11. Goebel, K. : Organography of Plants, Pt. II, Engl. ed., I905.

12. Hallier, H.: Ueber die Verwandtschaftsverhältnisse der Tubifloren und Ebenalen, den polyphyletischen Ursprung der Sympetalen und Apetalen, und die Anordnung der Angiospermen überhaupt. Abh. naturw. Ver. Hamburg, vol. xvi, I90I, p. I.

13. - Ueber Fuliania ... neue Beiträge zur Stammesgeschichte der Dicotyledonen. Beih. z. Bot. Centralbl., Abt. II, vol. xxiii, 1908. 
14. Kerner, A. : The Natural History of Plants, vol. ii, Engl. ed., I895.

15. Lignier, O., and Tison, A.: Les Gnétales, leurs fleurs et leur position systématique. Ann. des Sci. Nat., Bot., $9^{e}$ série, t. xvi, I9I 2.

16. Moss, C. E. : Modern Systems of Classification. New Phyt., vol. xi, 19I 2, p. 209.

17. Nawaschin, S.: Zur Embryobildung der Birke. Bull. Acad. Imp. Sci. St. Pétersbourg, vol. xiii, 1892 ; Bot. Centralbl., vol. liv, 1893, p. 345 .

18. : Ein neues Beispiel der Chalazogamie. Bot. Centralbl., vol. 1xiii, I895, p. 353.

19. Nicoloff, TH.: Sur le type floral et le développement du fruit des Juglandées. Journ. de Bot., vol. xviii, I904, p. I32.

20. Prante, K. : Beiträge zur Kenntniss der Cupuliferen. Bot. Jahrb., vol, viii, I887, p. 32 I.

21. Thompson, W. P. : On the Origin of the Multiseriate Ray of the Dicotyledons. Ann. of Bot., vol. xxv, Oct. 1911, p. 1005 .

22. Treub, M. : Sur les Casuarinées et leur place dans le système naturel. Ann. Jard. Bot. Buitenzorg, vol. $x$, I 891, pp. I 45-23I.

23. Van Tieghem, Ph.: Anatomie de la fleur femelle et du fruit du noyer. Bull. Soc. Bot. de France, vol. xvi, I869, p. $4^{12}$.

24. : Recherches sur la structure du pistil et sur l'anatomie comparée de la fleur, 1868, pp. 70, I 53 . 


\section{$2 \mathrm{BHL}$ Biodiversity Heritage Library}

Berridge, Emily Mary. 1914. "The structure of the flower of Fagaceae, and its bearing on the affinities of the group." Annals of botany 28, 509-526. https://doi.org/10.1093/oxfordjournals.aob.a089518.

View This Item Online: https://www.biodiversitylibrary.org/item/236856

DOI: https://doi.org/10.1093/oxfordjournals.aob.a089518

Permalink: https://www.biodiversitylibrary.org/partpdf/320036

\section{Holding Institution}

Smithsonian Libraries

\section{Sponsored by}

Biodiversity Heritage Library

\section{Copyright \& Reuse}

Copyright Status: Not in copyright. The BHL knows of no copyright restrictions on this item.

This document was created from content at the Biodiversity Heritage Library, the world's largest open access digital library for biodiversity literature and archives. Visit BHL at https://www.biodiversitylibrary.org. 